\title{
J. DAVID GREENSTONE
}

\section{In Memoriam}

With the death of J. David Greenstone on February 21, 1990, political science lost one of its most creative voices, and the Review of Politics lost a faithful friend. Professor Greenstone had served on the Review's editorial board since 1987. He was always generous with wise and fair advice, even during his long illness.

David Greenstone graduated from Harvard College in 1958 and went to Chicago for graduate studies, receiving his Ph.D. in 1963. $\mathrm{He}$ was to remain at Chicago for the rest of his career, occupying the Benton Professorship in Political Science at the time of his death. Professor Greenstone's scholarly career began with interests in group politics, city politics, and race. Over the years those interests evolved into an intense concern with the philosophical means for understanding the development of American politics. Among Professor Greenstone's scholarly contributions are Labor in American Politics (1968), Race and Authority in Urban Politics (1973) and a number of later, important essays exploring interpretative problems in American politics, appearing in his edited and co-authored Public Values and Private Power in American Politics (1982) as well as in various edited volumes and journals.

J. David Greenstone's influence on the study of politics will be lasting. His scholarship cast a new and clarifying light on key problems of American politics. His teaching shaped the identity of younger scholars whose own work grows from the seed of his intellectual passion. Here at the Review, J. David Greenstone's vision of a philosophically shaped inquiry into politics will continue to influence our work. 